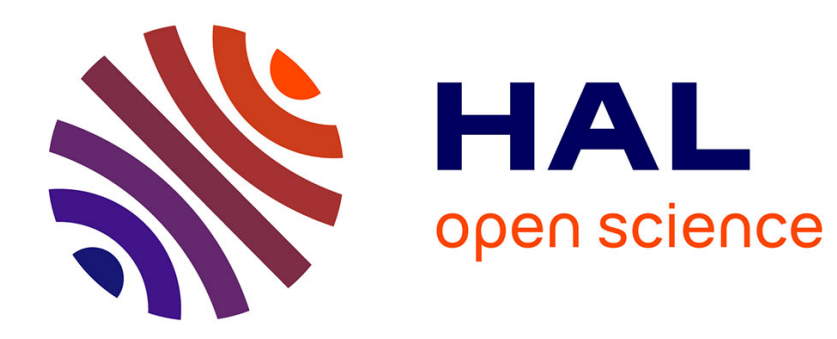

\title{
The wind-driven overturning circulation of the World Ocean
}

\author{
K. Döös
}

\section{To cite this version:}

K. Döös. The wind-driven overturning circulation of the World Ocean. Ocean Science Discussions, 2005, 2 (5), pp.473-505. hal-00298451

\section{HAL Id: hal-00298451 \\ https://hal.science/hal-00298451}

Submitted on 25 Nov 2005

HAL is a multi-disciplinary open access archive for the deposit and dissemination of scientific research documents, whether they are published or not. The documents may come from teaching and research institutions in France or abroad, or from public or private research centers.
L'archive ouverte pluridisciplinaire HAL, est destinée au dépôt et à la diffusion de documents scientifiques de niveau recherche, publiés ou non, émanant des établissements d'enseignement et de recherche français ou étrangers, des laboratoires publics ou privés. 
Ocean Science Discussions, 2, 473-505, 2005

www.ocean-science.net/osd/2/473/

SRef-ID: $1812-0822 /$ osd/2005-2-473

European Geosciences Union
OSD

2, 473-505, 2005

The wind-driven

overturning

Papers published in Ocean Science Discussions are under

open-access review for the journal Ocean Science

circulation of the

World Ocean

K. Döös

Title Page

\section{The wind-driven overturning circulation of the World Ocean}

\section{K. Döös}

Department of Meteorology, Stockholm University, 10691 Stockholm, Sweden

Received: 18 October 2005 - Accepted: 25 October 2005 - Published: 25 November 2005

Correspondence to: K. Döös (doos@misu.su.se)

(c) 2005 Author(s). This work is licensed under a Creative Commons License.

Abstract

Conclusions

Tables

14

4

Back

Full Screen / Esc

Print Version

Interactive Discussion 


\section{Abstract}

The wind driven aspects of the meridional overturning circulation of the world ocean and the Conveyor Belt is studied making use of a simple analytical model. The model consists of three reduced gravity layers with an inviscid Sverdrupian interior and a

5 western boundary layer. The net north-south exchange is made possible by setting appropriate western boundary conditions, so that most of the transport is confined to the western boundary layer, while the interior is the Sverdrupian solution to the wind stress. The flow across the equator is made possible by the change of potential vorticity by the Rayleigh friction in the western boundary layer, which is sufficient to permit water weak meridional pressure grac at the western boundary.

The model is applied to the World Ocean with a realistic wind stress. The amplitude of the Conveyor Belt is set by the northward Ekman transport in the Southern Ocean and the outcropping latitude of the NADW. It is in this way possible to set the amount of NADW that is pumped up from the deep ocean and driven northward by the wind and converted in the surface layer into less dense water by choosing the outcropping latitude and the depth of the layers at the western boundary. The model has proved to be able to simulate many of the key features of the Conveyor Belt and the meridional overturning cells of the World Ocean. This despite that there is no deep ocan mixing and that the water mass conversions in the this model are made at the surface.

\section{Introduction}

The meridional overturning is the most important mechanism of the world ocean to exchange mass and heat between latitudes and ocean basins. The density difference between the cold and salty water of the North Atlantic and the fresher and warmer waters of the Pacific and the Indian Ocean is believed to drive the largest overturning
OSD

2, 473-505, 2005

The wind-driven overturning circulation of the World Ocean

K. Döös

Title Page

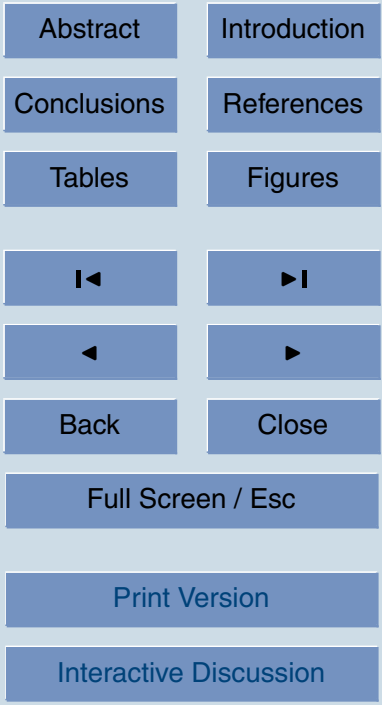

EGU 
cell in the ocean, known as the Conveyor belt (Broecker, 1991). The North Atlantic Deep Water (NADW), which is formed by convection, constitutes the deeper part of the Conveyor Belt. The NADW travels south through the Atlantic into the Southern Ocean, where the NADW is ventilated or continues in the deep ocean into the Pacific 5 or Indian Oceans. Once the water emerges at the surface it can return to the North Atlantic along the upper part of the Conveyor Belt. The return route has been a subject for discussion, whether the water comes mainly through the Drake Passage and then flows north into the Atlantic along the "cold water route" (Rintoul, 1991) or goes from the Pacific through the Indonesian Sea into the Indian Ocean around South Africa and 10 then into the Atlantic in the "warm water route" (Gordon, 1986).

The Conveyor Belt is thus the greatest inter-ocean exchange of mass and heat. The Conveyor Belt is often presented as a fundamentally non-linear phenomenon and is driven by the high-latitude buoyancy flow to the atmosphere and by deep convection. Accordingly it has been mostly discussed diagnostically using numerical general cir15 culation models (GCMs) (e.g. Drijfhout, 1996; Speich et al., 2002). Such discussions cannot examine the broader aspects of the physics involved because of the complexities (numerical and geographical) of the GCM solutions. However, it is possible to address many (but not all) aspects of the Conveyor Belt with simple, mostly analytical, models; this is the idea behind this article.

20 The purpose of this study is to explore to what extent the ocean overturning circulation and in particular the Conveyor Belt can be explained by the wind driven ocean dynamics. This will be done by using an as simple wind driven model as possible but that still captures the basic overturning circulation as seen in General Circulation Models (GCMs). The key features of the Conveyor Belt which must be included are a 25 pole-ward surface, and an equator-ward subsurface flow. The simplest model, which would include these, is a layered model. We choose a three-and-a-half layered model similar to that of Döös (1994) and Nof (2003). This choice automatically brings some disadvantages, chief among which is the lack of thermodynamics. At first sight this may seen a telling difficulty, since deep convection, one essential component of the

The wind-driven overturning circulation of the World Ocean

K. Döös

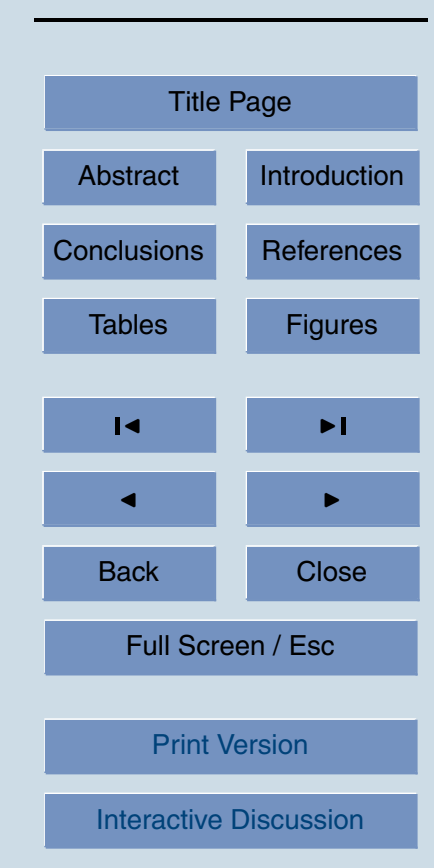

EGU 
Conveyor Belt, is explicitly excluded in what is primarily a wind-driven model. Although there are ad hoc methods for including thermodynamics in a layered model, these are unsatisfactory and remove the clarity sought in the first place. Accordingly, all areas where thermodynamics play a crucial role are placed logically and geographically be5 yond the boundaries of the model. The amplitude of the Conveyor Belt must then be provided for the model.

A description of the model is presented in Sect. 2. The model is applied to the World Ocean together with a fine resolution primitive equation model in Sect. 3. The simulation of the wind driven cells with a particular focus on the Conveyor Belt is presented in Sect. 4 followed by a discussion and conclusions in Sect. 5.

\section{The wind-driven overturning circulation of the World Ocean}

K. Döös

\section{The analytical model}

The dynamics of the model are Sverdrupian in the interior with a Stommel layer at the western boundary (Stommel, 1948). By including a western boundary layer it is possible to calculate net meridional transports and the corresponding meridional overturning stream function. Three reduced gravity layers are used, and an Ekman layer in the extra-equatorial regions. The physical model is shown in Figs. 1 and 2. The equations of motion for the Ekman layer are:

$$
\begin{aligned}
& -f v_{E}=\frac{T^{x}}{\rho_{0} h_{E}} \\
& f u_{E}=\frac{T^{y}}{\rho_{0} h_{E}} \\
& w_{E}=\frac{1}{\rho_{0}} \nabla \times\left(\frac{T^{W}}{f}\right)
\end{aligned}
$$

The equations of motion and the continuity equation for layer 1 are:

Title Page

Abstract

Conclusions

Tables

14

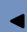

Back

Full Screen / Esc

Print Version

$-f v_{1}=-\frac{\partial G_{1}}{\partial x}$

$f u_{1}=-\frac{\partial G_{1}}{\partial y}-\Gamma v_{1}$

$20 \frac{\partial u_{1}}{\partial x}+\frac{\partial v_{1}}{\partial y}+\frac{\partial w_{1}}{\partial z}=0$ 
and for layer 2:

$-f v_{2}=-\frac{\partial G_{2}}{\partial x}$

$f u_{2}=-\frac{\partial G_{2}}{\partial y}-\Gamma v_{2}$

2, 473-505, 2005

$\frac{\partial u_{2}}{\partial x}+\frac{\partial v_{2}}{\partial y}+\frac{\partial w_{2}}{\partial z}=0$

The wind-driven

overturning

and for layer 3:

$-f v_{3}=-\frac{\partial G_{3}}{\partial x}$

$f u_{3}=-\frac{\partial G_{3}}{\partial y}-\Gamma v_{3}$

circulation of the

World Ocean

$\frac{\partial u_{3}}{\partial x}+\frac{\partial v_{3}}{\partial y}+\frac{\partial w_{3}}{\partial z}=0$

K. Döös

where for simplicity the coordinates are Cartesian here but all the calculations have been made with spherical coordinates. $x$ is pointing eastward, $y$ northward, $f$ is the Coriolis parameter as a function of latitude, $h_{n}$ is the n-th layer's thickness and $G_{1} \equiv \gamma_{1} h_{1}+G_{2}, G_{2} \equiv \gamma_{2}\left(h_{1}+h_{2}\right)+G_{3}$ and $G_{3} \equiv \gamma_{3}\left(h_{1}+h_{2}+h_{3}\right) . \quad \Gamma$ is the bottom friction coefficient. Under the Boussinesq approximation a reference density can be used in the denominator for the reduced gravity in each active layer so that $\gamma_{n} \equiv 2 g\left(\rho_{n+1}-\rho_{n}\right) /\left(\rho_{n+1}+\rho_{n}\right)$ is the reduced gravity. $T^{X}$ and $T^{Y}$ are the zonal and meridional wind stresses and $T^{W}\left(T^{X}, T^{Y}\right)$ is the wind stress vector. Layer 4 is inert due to our reduced-gravity assumption.

The model is constructed in a similar way as Stommel (1948) solved the western boundary current problem by separating the ocean in in a frictionless interior and a western boundary layer with linear friction.

\subsection{Interior of the ocean}

The dynamics are Sverdrupian in the interior of the ocean, i.e. under the Ekman layer and outside the western boundary layer, where the friction terms are small. The equa-

tions can here be solved using the equations for the ventilated thermocline by Luten

Title Page

Abstract

Introduction

Conclusions

References

Tables

Figures

14

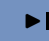

$<$

Back

Close

Full Screen / Esc

Print Version

Interactive Discussion 
et al. (1983) (hereafter denoted LPS). These solutions are presented in the Appendix. The LPS theory has of course in its simplicity many limitations such as e.g. that all but one active layer must vanish on the eastern boundary. Moreover, the thickness of that layer defines the width of the "shadow zones" in the solution. From the depths of the 5 layer interfaces it is possible to calculate the meridional velocity fields geostrophically everywhere except at the equator.

\subsection{Western boundary layer}

The friction is only kept in the western boundary layer as a linear Rayleigh friction in the meridional equation. The other friction terms have been neglected. The friction in the zonal equation of momentum will otherwise only have a smoothing effect on the solutions. Note however, that in order to have a more realistic parameterisation of the the friction one can use e.g. Laplacian viscosity (Munk, 1950) in particular at the Equator where it plays an essential role in the strong zonal Equatorial currents. This has been tested but does not alter the results and we have therefore chosen to keep the model as simple as possible. In order to simulate the Equatorial currents one requires vertical advection and friction of momentum between the layers which is a degree of complexity above the present model, which would anyhow not contribute to the meridional overturning circulation.

From (2)-(4) it is possible to derive equations for the layer thicknesses $h_{1}, h_{2}$ and $h_{3}$ :

$\Gamma \frac{\partial}{\partial x}\left(h_{1} \frac{\partial G_{1}}{\partial x}\right)+\beta h_{1} \frac{\partial G_{1}}{\partial x}=f J\left(G_{1}, h_{1}\right)-f^{2} w_{E}$

$\Gamma \frac{\partial}{\partial x}\left(h_{2} \frac{\partial G_{2}}{\partial x}\right)+\beta h_{2} \frac{\partial G_{2}}{\partial x}=f J\left(G_{2}, h_{2}\right)$

$\Gamma \frac{\partial}{\partial x}\left(h_{3} \frac{\partial G_{3}}{\partial x}\right)+\beta h_{3} \frac{\partial G_{3}}{\partial x}=f J\left(G_{3}, h_{3}\right)$

where $\beta \equiv \partial f / \partial y$ and the Jacobian $J(a, b) \equiv \frac{\partial a}{\partial x} \frac{\partial b}{\partial y}-\frac{\partial a}{\partial y} \frac{\partial b}{\partial x}$.

The layer thicknesses $h_{n}$, can be solved with Eq. (5) at all latitudes. Different solutions will be found for the interior of the ocean, the western boundary layer and the

The wind-driven overturning circulation of the World Ocean

K. Döös

Title Page

Abstract Introduction

Conclusions References

Tables Figures

14 $\rightarrow$

$\triangleleft$

Back

Close

Full Screen / Esc

Print Version

Interactive Discussion

EGU 
Equatorial region.

In the western boundary layer the friction terms balances the planetary vorticity. A second order ordinary differential Eq. (5) is obtained which cannot be solved analytically in the western boundary region except for when only one layer is active (Stommel,

5 1948). Thus, the solution in this region must be obtained numerically. These types of equations are often integrated in time but since these equations are time independent they have to be solved with an iterative numerical solution of Eq. (5). The solution converges within a few iteration to a unique solution. The choice of friction determines the width of the western boundary layer. With a friction coefficient of $\Gamma=1 /(7$ days), the 10 Stommel layer thickness $(\delta=\Gamma / \beta)$ is in the zonal direction $0.7^{\circ}$ at the Equator and $2.6^{\circ}$ at $60^{\circ}$. The width of the western boundary region, where the iterative semi-analytical solution is applied, is set to $5^{\circ}$, so that the boundary layer is well solved at all latitudes. This type of model is otherwise insensitive to the choice of friction coefficient and the simulated overturning circulation does not alter.

15 The depths of the layer interfaces in Eq. (5) require three western boundary conditions, which are set by the total northward transport in each layer $V_{n}=\int_{x_{W}}^{x_{E}} v_{n} h_{n} d x$ which in turn is determined geostrophically from zonal momentum equations in Eqs. (2)-(4) by the depth at the western boundary so that

$$
\begin{aligned}
& V_{1}=\int_{X_{W}}^{X_{E}} \frac{h_{1}}{f} \frac{\partial G_{1}}{\partial x} d x \\
& V_{2}=\int_{X_{W}}^{X_{E}} \frac{h_{2}}{f} \frac{\partial G_{2}}{\partial x} d x \\
& V_{3}=\int_{X_{W}}^{X_{E}} \frac{h_{3}}{f} \frac{\partial G_{3}}{\partial x} d x
\end{aligned}
$$

where the indices $W$ and $E$ indicate respectively the western and eastern boundaries. Using these expressions it is possible to calculate numerically by simple iteration the depths of the layers at the western boundary corresponding to a meridional transport $V_{n}$ for each layer.
The wind-driven overturning circulation of the World Ocean

K. Döös

Title Page

Abstract Introduction

Conclusions References

Tables Figures

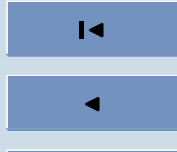

$\rightarrow$ I

Back

Close

Full Screen / Esc

Print Version

Interactive Discussion 
$V_{1}+V_{2}+V_{3}+V_{e}=$

$\frac{\gamma_{3}}{2 f}\left(D_{E}^{2}-D_{W}^{2}\right)+\frac{\gamma_{2}}{2 f}\left(H_{E}^{2}-H_{W}^{2}\right)-$

$\frac{\gamma_{1}}{2 f} h_{1 W}^{2}-\frac{1}{f \rho_{0}} \int_{X_{W}}^{X_{E}} T^{x} d x$

where $D$ is the depth of layer 3 and $H$ is the depth of layer 2 . The individual values of the meridional transport $V_{n}$ that sets the three western boundary conditions will be 5 discussed in Sect. 4 for each ocean basin.

\subsection{Application of the model to the World Ocean}

We now apply the model to the World Ocean. The aim is to see to what extent the model can simulate the meridional overturning cells. The wind stress used is the yearly average of the ECMWF climatology analysis by Trenberth et al. (1989). The LPS regions (see Appendix), which determine the dynamics of the interior solution, are presented in Fig. 3. LPS argued in their study that their particular choice of density layers were arbitrary. The choice is however here close to theirs: $\rho_{1}=1025.5 \mathrm{~kg} / \mathrm{m}^{3}$, $\rho_{2}=1027.2 \mathrm{~kg} / \mathrm{m}^{3}, \rho_{3}=1027.55 \mathrm{~kg} / \mathrm{m}^{3}$ and $\rho_{4}=1028.2 \mathrm{~kg} / \mathrm{m}^{3}$. The depths of the interfaces between layer 2, 3 and 4 at the eastern boundary have been chosen to

${ }_{15} H_{E}=1400 \mathrm{~m}$ and $D_{E}=3200 \mathrm{~m}$. The choice of these depths have been made to fit the depths of the deep branches of the meridional cells in OCCAM. Different values of the depths will simply move the meridional circulation up or down. The deepest layer 3 is in the interior only active in the very southern Southern Ocean where layer 2 outcrops because of the strong Ekman upwelling. All layers with non zero depths are active in the western boundary layer governed by Eq. (5). The depths of the interfaces between the layers are presented in Fig. 4.

Since the model has no active thermodynamics it cannot simulate the positions of the outcropping latitudes $y_{2 N}$ and $y_{2 s}$. They are instead prescribed and are presented in Table 1. These chosen latitudes are also shown in comparison with the sea surface

The wind-driven overturning circulation of the World Ocean

K. Döös

Title Page

Abstract Introduction

Conclusions References

Tables Figures

14

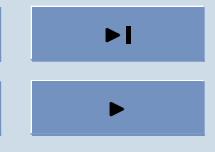

Back

Close

Full Screen / Esc

Print Version

Interactive Discussion

EGU 
density in OCCAM in Fig. 5. The thermohaline forcing is also set by the outcropping latitude $y_{3}$ in the Southern Ocean, which is set indirectly by the choice of the depth of layer three at the eastern boundary $\left(D_{E}\right)$.

\subsection{Equatorial region}

5 At the Equator, where the Ekman dynamics are not valid, we need to apply the wind stress directly to the shallowest reduced gravity layer. The depths of the layers for the interior of the ocean can be solved from Eq. (5). The difference is, however, that there is no meridional Ekman transport above the surface layer, implying that the meridional velocities cannot be calculated from the geostrophic velocities. Instead they have to be obtained by applying directly the wind stress on the shallowest reduced gravity layer. The deep layers, which are not in contact with the surface, are of constant interface depths along the equator. Only the interface depth between the surface layer and the layer below will be affected by the wind stress. If layer 1 is non zero then the zonal equations of motions in Eqs. (1)-(4) are replaced by

$0=-\gamma_{3} \frac{\partial D}{\partial x}-\gamma_{2} \frac{\partial H}{\partial x}-\gamma_{1} \frac{\partial h_{1}}{\partial x}+\frac{T^{x}}{\rho_{0} h_{1}}$

$0=-\gamma_{3} \frac{\partial D}{\partial x}-\gamma_{2} \frac{\partial H}{\partial x}$

From which it is possible to derive expressions for the layer interfaces by integrating from the eastern boundary with the appropriate eastern boundary conditions:

$$
\begin{aligned}
& h_{1}(x)=\sqrt{h_{1 E}^{2}-\frac{2}{\gamma_{1} \rho_{0}} \int_{x}^{x_{E}} T^{x} d x^{\prime}} \\
& H(x)=H_{E} \\
& D(x)=D_{E}
\end{aligned}
$$

2, 473-505, 2005

\section{The wind-driven overturning circulation of the World Ocean}

K. Döös

\section{Title Page}

Abstract Introduction

Conclusions References

Tables Figures
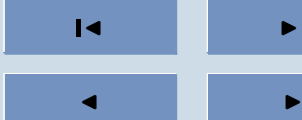

Back

Close

Full Screen / Esc

Print Version

Interactive Discussion 
$h_{1}(x)=0$

$H(x)=\sqrt{H_{E}^{2}-\frac{2}{\gamma_{2} \rho_{0}} \int_{x}^{x_{E}} T^{x} d x^{\prime}}$,

$D(x)=D_{E}$

2, 473-505, 2005

In the interior these equations are identical to the LPS solutions given in the Appendix for the eastern shadow zone and the two layer solutions. In the western boundary 5 region the matching is also without any discontinuity as seen in Fig. 6 , which is a result of the meridional "mixing" arising from the Jacobian in Eq. (5).

Away from the western boundary, it is the zonally static solution for the equatorial region where the zonal pressure gradient is balanced by the zonal wind stress. The equatorial currents are filtered out since there is no vertical advection, nor vertical dif10 fusion of momentum in the zonal Eqs. (2)-(4). Apart from the Sverdrupian wind driven surface layer currents the cross Equatorial flow has to take place in the western boundary layer. This is possible if there is a meridional pressure gradient, the meridional equations in Eqs. (2)-(4) become at the equator:

$$
\begin{aligned}
& v_{1}=-\frac{1}{\Gamma} \frac{\partial G_{1}}{\partial x} \\
& v_{2}=-\frac{1}{\Gamma} \frac{\partial G_{2}}{\partial x} \\
& v_{3}=-\frac{1}{\Gamma} \frac{\partial G_{3}}{\partial x}
\end{aligned}
$$

15 The depth of the layer interfaces at the western boundary (Fig. 6), which we calculated in the previous paragraph, have clear meridional gradients, which will enable the water to cross the equator. Water flow across the equator is far from understood, since it requires a change in sign of the potential vorticity. In this analytical model the Rayleigh friction is adequate to change this sign of the potential vorticity, but no claims are made other than this is the simplest addition to the wind driven geostrophic dynamics which permit inter-hemisphere transports. Since this friction is also necessary to close the western boundary layer, there is no need to make use of more complex

\section{The wind-driven overturning circulation of the World Ocean}

K. Döös

Title Page

Abstract Introduction

Conclusions

Tables References

Figures

14

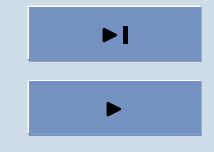

Back

Close

Full Screen / Esc

Print Version

Interactive Discussion 
dynamics. Note also that the depth of the layer interfaces at the western boundary in Fig. 6, depends on the shape of the western boundary and the strength of the Sverdrup Circulation at the western boundary. This is why the meridional gradient of the depths of the layer interfaces at the western boundary in the Atlantic changes sign at 5 around $40^{\circ} \mathrm{N}$ where, the Sverdrup circulation changes sign and the American coast line reaches its easternmost longitude. This is also where the biggest changes of the coastline occurs, which explains the rather noisy behaviour of the depths of the layer interfaces.

\section{The Ocean general circulation model OCCAM}

10 The aim is of the present study is to see to what extent our model model can simulate the meridional overturning cells. At the present date, only numerical models can provide complete pictures of the world meridional circulation. However observational data do exist in some key areas of the world ocean but it is beyond the scope of this paper to validate the numerical models. We have here opted to use the general circulation model OCCAM to represent the "true" ocean circulation.

OCCAM has a horizontal $1 / 4^{\circ}$ resolution at the equator with 66 depth levels. The used model integration are taken from the years 1991 to 2002 (Marsh et al., 2005). The meridional stream function from OCCAM is presented in Figs. 7 and 8 for the different world ocean basins defined in Fig. 9. The Atlantic, North Pacific and Southern Ocean have nearly zero net meridional transport apart from $0.6 \mathrm{~Sv}\left(1 \mathrm{~Sv}=10^{6} \mathrm{~m} / \mathrm{s}^{2}\right)$ through the Bering Strait. There is a net barotropic circulation of about $13 \mathrm{~Sv}$ around Australia, which flows through the Indonesian Sea. The meridional stream function is therefore by integrating from the bottom and up to the surface, $13 \mathrm{~Sv}$ in the Pacific west of Australia and -13 Sv in the Indian and the Indo-Atlantic east of Australia. The Indian and Pacific have been split up in the middle of the Indonesian Sea. The stream function is hence gradually decreasing to zero at the surface between the north Australian continent and

OSD

2, 473-505, 2005

The wind-driven overturning circulation of the World Ocean

K. Döös

Title Page
Abstract

Conclusions

Tables

14

$\triangleleft$

Back
Introduction

References

Figures

$\rightarrow$

$\checkmark$

Close
Full Screen / Esc

Print Version

Interactive Discussion 
the south Asian continent.

The key feature of the meridional circulation is the Conveyor Belt, which is clearly illustrated by the cell in the Atlantic with a maximum of $18 \mathrm{~Sv}$ at $30^{\circ} \mathrm{S}$ at about $1500 \mathrm{~m}$ depth. This cell decreases towards the north, and in the very north corresponds to

5 the formation of the North Atlantic Deep Water (NADW). Further south it can unfortunately not correspond to any real formation of NADW since in this region the surface conditions are not such as can significantly contribute to the NADW south of $50^{\circ} \mathrm{N}$, and thereby intensify the spin-up process in OCCAM.

\section{The overturning circulation simulated by the analytical model}

10 In order to understand the simulation of the ocean circulation and in particular its overturning component we will follow the path of the Conveyor Belt from the Southern Ocean where the NADW upwells and around the cycle in the world ocean. A schematic view of the model is presented in Fig. 2 with corresponding outcropping latitudes as well as density layer transports. The choices of outcropping latitudes in the 15 analytical model presented in Table 1 determine the water mass exchange between the density layers by the Ekman transport in the Ekman layers across these latitudes.

\subsection{The Southern Ocean}

The NADW upwells from the deep ocean (layer 3) into the Ekman layer at the surface of the Southern Ocean. It is the amplitude of the northward Ekman transport from layer 3 into layer 2 across their interface at $y_{3 S}(x)$ sets the amplitude of the Conveyor Belt:

$V_{C B}=E\left(y_{3 S}(x)\right)$

where $E$ is the zonally integrated Ekman transport across the line $y_{3 S}(x)$ (see Fig. 2). Once the NADW is in the Ekman layer it changes water mass characteristics during its flow northward into layer 2 across $y_{3 S}(x)$. This is the driving force of the Conveyor

OSD

2, 473-505, 2005

The wind-driven overturning circulation of the World Ocean

K. Döös

Title Page
Abstract

Conclusions

Tables

14

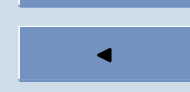

Back
Introduction

References

Figures

- I

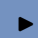

Close
Full Screen / Esc

Print Version

Interactive Discussion 
Belt in this analytical model. The strength of the conveyor belt $\left(V_{C B}\right)$ is in the analytical model $16 \mathrm{~Sv}$, which can be compared with the $18 \mathrm{~Sv}$ by the OCCAM integration. Most estimates are between 16 and $20 \mathrm{~Sv}$ by different numerical simulations (Semtner and Chervin, 1992; Stevens and Thompson, 1994). The inverse model based 5 on hydrographic data by Ganachaud and Wunch (2000) estimates the Conveyor Belt component in the South Atlantic to $16 \pm 3 \mathrm{~Sv}$.

The transport continues north in the Ekman layer and layer 2:

$$
V_{2}(y)+E(y)=V_{C B} \text { for } y_{3}(x) \leq y \leq y_{\text {Aus }}
$$

where $V_{2}$ is the total transport of layer 2. At the latitude of south Australia $\left(y_{\text {Aus }}=44^{\circ} \mathrm{S}\right)$, the northward flowing Conveyor Belt is split up into one branch that flows into the the Pacific and one into the Indo-Atlantic.

There is also an Antarctic Bottom Water (AABW) Cell simulated by the analytical model in the Southern ocean. There is however no northward penetration of the AABW cell in the world ocean as in the OCCAM integration. The AABW Cell is instead only 15 a one layer cell in the Southern Ocean. The reason for this is that we do not have any subsurface diapycnal mixing in our simple analytical model. The AABW is in OCCAM mixing with less dense water such as the NADW. Although the AABW is loosing relatively little buoyancy in OCCAM, which explains why the AABW Cell is very thin in the stream function as a function of density in Fig. 8, it still corresponds to a vertical 20 displacement of several thousands of meters in Fig. 7 since the ocean is only weekly stratified in the deep ocean.

\subsection{The Pacific Ocean}

The total transport into the Pacific is also the transport through the Indonesian Sea $\left(V_{T F}\right)$ since we do not have any evaporation-precipitation and that Bering Strait is

closed. The amplitude of the Indonesian through flow is in our model set by how much water is converted from intermediate water of layer 2 into tropical water of layer 1 . This is in turn forced by the equatorward Ekman transport across the outcropping latitudes

OSD

2, 473-505, 2005

The wind-driven overturning circulation of the World Ocean

K. Döös

Title Page

Abstract Introduction

Conclusions

Tables References Figures

14

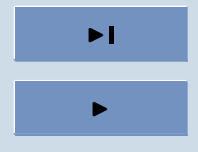

4

Back

Close

Full Screen / Esc

Print Version

Interactive Discussion

EGU 
of $y_{2 S}$ and $y_{2 N}$ between layer 1 and 2 in the Pacific so that the Indonesian through flow is

$V_{T F}=E_{P}\left(y_{2 S}\right)-E_{P}\left(y_{2 N}\right)$

2, 473-505, 2005

Note that in our analytical model there is no deep water (NADW or AABW) flowing into 5 the Pacific, since all the NADW upwells in the Southern Ocean. At $y_{\text {Ind }}$ the Conveyor Belt flows through Indonesian Sea and into the Indian. By using our chosen values of outcropping latitudes in Table 1 we obtain an Indonesian through flow transport of $V_{T F}=9.3 \mathrm{~Sv}$, which is lower than that of the $13 \mathrm{~Sv}$ of the OCCAM integration and the estimated $16 \pm 5$ Sv by Ganachaud and Wunsh (2000).

The Indonesian through flow enters the Indian where it continues south together with the return flow of the northward Ekman transport. The model fails to find a pure LPS solution in the Indian basin that satisfies the boundary conditions without having a negative depth at the western boundary, which would have no physical meaning. A depth of $450 \mathrm{~m}$ at the eastern boundary for layer 1 has therefore been applied instead of the usual $h_{1 E}=0$. This implies unfortunately an inconsistency with a discontinuity of the layer 1 thickness at the eastern boundary between the Indo-Atlantic and the Indian $\left(x_{E}, y_{\text {Afr }}\right)$. Döös (1994) argued that the failure of the LPS theory in the Indian could be linked to the southward boundary current along the coast of Australia (Leeuwin Current).

The Conveyor Belt can now continue its path along the African coast into the Aghulas Current and then turns around at and enters the Atlantic Basin into layer 2.

\subsection{The Indo-Atlantic}

Let us now return to the latitude of South Australia $\left(y_{\text {Aus }}\right)$, and follow the northward 25 transport that enters the Indo-Atlantic from the Southern Ocean Basin in layer 2 and

\section{The wind-driven overturning circulation of the World Ocean}

K. Döös

Title Page

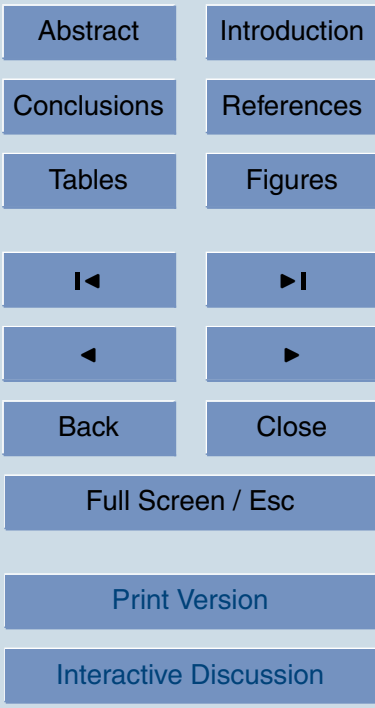

EGU 
the Ekman layer where

$V_{2}(y)+E(y)=V_{C B}-V_{T F}$ for $\quad y_{\text {Aus }} \leq y \leq y_{2 S}$

2, 473-505, 2005

But since the northward Ekman transport is $E(y)>V_{C B}-V_{T F}$ we must have $V_{2}(y)<0$, which becomes a southward return flow forming the Deacon Cell, which is the anti5 clockwise cell in the Indo-Atlantic. The outcropping latitude $y_{2 S}$ determines the strength of the Deacon Cell, since all the water that does not continue north in the Ekman layer at $y_{2 S}$ must return south in layer 2 . The depth of the Deacon Cell is deeper in OCCAM than in our model. Döös (1994) demonstrated however that by having an eastern boundary depth of layer $2\left(H_{E}\right)$ of $2750 \mathrm{~m}$ instead of the present $1400 \mathrm{~m}$ it was possible 10 to simulate the Deacon Cell at the right depth.

The transport in layer 2 north of $y_{2 S}$ is

$V_{2}(y)=V_{C B}-E\left(y_{2 N}\right)-V_{T F}$ for $y_{2 S} \leq y \leq y_{\text {Afr }}$

The wind-driven overturning circulation of the World Ocean

K. Döös

Title Page

4.5. The Atlantic Basin

The two shallow branches of the Conveyor Belt, which are sometimes referred in the 15 literature to as the Warm and Cold Water Paths, merge at $y_{\text {Afr }}$ when they flow north into the Atlantic Basin. The transport through the surface layers is driven by the Ekman transport at the outcropping latitude in the north Atlantic:

$V_{1}(y)-E(y)=E\left(y_{2 N}\right)$ for $y_{\text {Afr }} \leq y \leq y_{2 N}$

The transport in layer 2 is hence by continuity:

${ }_{20} \quad V_{2}=V_{C B}-E\left(y_{2 N}\right)$ for $y_{\text {Afr }} \leq y \leq y_{2 N}$

Abstract

Conclusions

Tables

14

$\triangleleft$

Back

Full Screen / Esc

Print Version termediate branch. At the outcropping latitude in the North Atlantic the two branches merge in layer 2 and continue north to the convection area:

$V_{2}(y)=V_{C B}-E(y)$ for $y_{2 N} \leq y \leq y_{C}$

Interactive Discussion

EGU
Introduction

References

Figures

- I

$\checkmark$

Close 
This model can of course not simulate the convection processes that enables the formation of NADW in layer three. The convection from layer 2 to layer 3 takes place between the latitudes $y_{C}$ and $y_{N}$. This convection zone only prescribes the transport from layer two to layer three where the NADW starts its southward journey:

${ }_{5} V_{2}=-V_{3}=\frac{y_{N}-y}{y_{N}-y_{C}} V_{C B}$ for $y_{C} \leq y \leq y_{N}$

The NADW flows south in layer 3 without any exchange to other layers until it outcrops in the Southern Ocean at $y_{3}(x)$, which brings us back to where we started to trace the Conveyor Belt.

\subsection{The tropical cells}

10 The tropical shallow meridional cells in the three oceans are all simulated in our analytical model. They are driven by the poleward Ekman transport away from the equator which in turn creates an upwelling at the equator. The poleward flowing water in the Ekman layer is gradually sucked back into layer 1 and return to the equator in the subsurface. The present models can hence without any real sub-surface diapycnal mixing

simulate the tropical cells. The model however cannot simulate this straight on the equator where the Coriolis term is cancelled. In the real continuously stratified ocean a diapycnal mixing is of course necessary for the equatorial upwelling. The diapycnal mixing will shape the form of the thermocline but the basic driving mechanism as well as the overturning circulation can be explain by this simple Ekman drift divergence.

\subsection{The cross equatorial flow}

The horizontal stream functions for the three layers can be calculated by applying the wind stress directly on layer 1 without an Ekman layer, in order to avoid the discontinuity at the equator. Figure 10 shows the horizontal stream function for the three layers. The deep layer transports the NADW in the western boundary layer south- ward across the equator. In this way the horizontal stream function is equal to $V_{C B}$
OSD

2, 473-505, 2005

The wind-driven overturning circulation of the World Ocean

K. Döös

Title Page

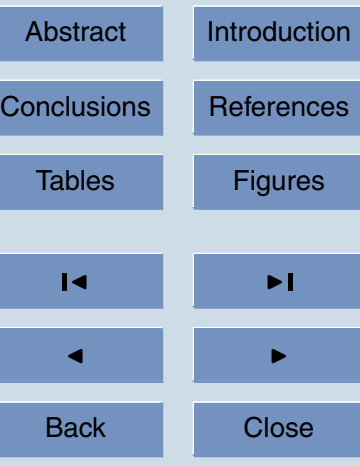

Full Screen / Esc

Print Version

Interactive Discussion 
on the western boundary in layer 3 when not in contact with the sea surface so that $\psi_{3}\left(x_{\text {west }}, y\right)=-V_{C B}$. The northward return flow is also confined in the western boundary layer but split between layers 1 and 2 so that the stream function for layer 2 is $\psi_{2}\left(x_{\text {west }}, y\right)=V_{C B}-E\left(y_{2 N}\right)$. Layer 1 has, in addition to, a wind driven Stommel-Sverdrup 5 circulation added, which has no net meridional transport in the layer.

Note also that the reason the stream lines seem to cross the topography in Fig. 10 is simply because only the western-most values are satisfying the boundary conditions.

\section{Discussion and conclusions}

This study has shown it is possible to simulate many of the aspects of the world ocean overturning circulation and the Conveyor Belt with a wind driven analytical model. This despite that there is no deep ocan mixing and that the water mass conversions in the this model are made at the surface or just below the surface at the Equator. The model obeys Sverdrupian dynamics in the interior and Stommel dynamics in the western boundary layer. The dynamics in this model are hence to a large extent wind driven.

15 There is however an indirect thermohaline forcing that consists in the choosing the latitudes of the density layers outcropping. The choices of the the model parameters in the present study have been done in order to obtain as realistic results as possible, which is in our case as close as possible to the OCCAM model simulation.

The amplitude of the Conveyor Belt is in this simple model driven by the northward 20 Ekman transport in the Southern Ocean and therefore set by the outcropping latitude of the NADW. It is hence possible to set the amount of NADW that is pumped up from layer 3 into the Ekman layer and driven northward by the wind. The water is then converted in the surface Ekman layer into less dense water when it crosses the outcropping latitude $y_{35}$ between layer 2 and 3 . This water mass conversion mechanism in the Southern 25 Ocean was described as the major upwelling zone of North Atlantic Deep Water in the OCCAM integration by Döös and Coward (1997).

The tropical shallow meridional cells are driven by the poleward Ekman transport

OSD

2, 473-505, 2005

The wind-driven overturning circulation of the World Ocean

K. Döös

Title Page

Abstract Introduction

Conclusions

Tables References Figures

14

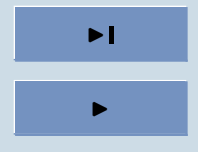

4

Back

Close

Full Screen / Esc

Print Version

Interactive Discussion 
away from the equator which in turn creates an upwelling at the equator. The poleward flowing water in the Ekman layer is gradually sucked down and return to the equator in the sub-surface. The present models can hence without any real sub-surface diapycnal mixing simulate the tropical cells. The model however cannot simulate this 5 straight on the equator where the Coriolis term is cancelled. In the real continuously stratified ocean a diapycnal mixing is of course necessary for the equatorial upwelling. The diapycnal mixing will shape the form of the thermocline but the basic driving mechanism as well as the overturning circulation can be explain by this simple Ekman drift divergence.

10 The equator is often described as a barrier between the two hemispheres (Killworth, 1991). If the potential vorticity is required to be preserved then only waters that posses enough relative vorticity may be able to cross the equator since the planetary vorticity changes sign here. In this study we have included friction in the western boundary layer so that the potential vorticity does not need to be preserved. The vorticity equation obtained from Eqs. (2)-(4) is

$\beta v_{n}=f \frac{\partial w}{\partial z}+A \frac{\partial^{3} v_{n}}{\partial x^{3}}$

\section{The wind-driven overturning circulation of the World Ocean}

K. Döös

An expression of the potential vorticity $\left(f / h_{n}\right)$ for the layers is obtained by integrating over each layer

$u_{n} \frac{\partial}{\partial x}\left(\frac{f}{h_{n}}\right)+v_{n} \frac{\partial}{\partial y}\left(\frac{f}{h_{n}}\right)=\frac{A}{h_{n}} \frac{\partial^{3} v_{n}}{\partial x^{3}}+\delta f w_{E}$

20 where $\delta=1$, for layers in contact with the surface and $\delta=0$, for layers that are not exposed to the Ekman pumping at the ocean surface. The right hand side will thus enable the potential vorticity to change. The water in the subsurface layers can thus cross the equator if $\frac{\partial^{3} v_{n}}{\partial x^{3}} \neq 0$. From the meridional moment equations in Eqs. (2)-(4), we see that the only requirement for the water to cross the equator is that there is a meridional

Title Page

Abstract

Conclusions

Tables

Figures

14

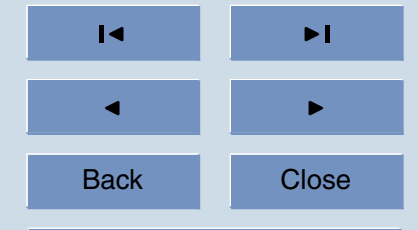

Back

Introduction

References

Full Screen / Esc

Print Version

Interactive Discussion

EGU 
similarly be done with a pressure gradient in both the zonal and meridional direction $\left(\frac{\partial^{2} p}{\partial x \partial y} \neq 0\right)$. This pressure gradient arises naturally from the transport conditions which sets the depths of the layer interfaces at the western boundary (Fig. 6).

The model cannot however simulate properly the deep Antarctic Bottom Water Cell 5 since it is only ventilated at the surface near Antarctica.

Water mass characteristics in the abyssal ocean by diapycnal mixing with less dense water such as the NADW. This mixing is however very weak and does not transform much the AABW characteristics but is still enough to drive a large overturning cell in the deep abyssal ocean.

10 Although the AABW is loosing relatively little buoyancy in OCCAM, which explains why the AABW Cell is very thin in the stream function as a function of density in Fig. 8, it still corresponds to a vertical displacement of several thousands of meters in Fig. 7 since the ocean is only weekly stratified in the deep ocean.

By comparing the results with those of a GCM, it has been possible to identify what 15 in the Conveyor Belt is directly due to the Stommel-Sverdrupian dynamics and what is due to the thermohaline forcing. It is of course not possible to separate completely the two types of forcing since it is a non-linear process, but it has nevertheless been very clear that once the outcropping latitudes have been prescribed that the model reproduces many of the aspects of the overturning circulation in the world ocean with no deep ocean mixing.

\section{Appendix of the LPS interior solution}

The solutions for the interior of the ocean, east of the western boundary layer and beneath the Ekman layer, where the friction is negligible, is here presented for the different regions based on the LPS theory. For further details see LPS. The Sverdrup

The wind-driven overturning circulation of the World Ocean

K. Döös

Title Page

Abstract Introduction

Conclusions

Tables References Figures

14

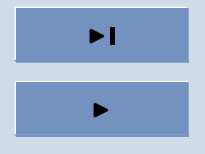

$\triangleleft$

Back

Close

Full Screen / Esc

Print Version

Interactive Discussion 
function is defined as

$S^{2}(x, y) \equiv-\frac{2 f}{\rho_{0} \gamma_{2} \beta} \int_{x}^{x_{E}} \nabla \times T^{W} d x^{\prime}-\frac{2}{\rho_{0} \gamma_{2}} \int_{x}^{x_{E}} T^{x} d x^{\prime}$

The solutions are divided into 5 parts corresponding to the different regions in Fig. 3.

1. One layer for $S^{2}(x, y)+H_{E}^{2} \leq 0$, which is limited by the the line $y_{3 S}$, which is defined as $S^{2}\left(x, y_{3 S}\right)=-H_{E}^{2}$

$h_{1}=h_{2}=0$ and $h_{3}=\sqrt{\frac{\gamma_{2}}{\gamma_{3}} S^{2}(x, y)+D_{E}^{2}}$

2. Two layers for $y_{3 S} \leq y \leq y_{2 S}$ or $y_{2 N} \leq y$ or $S^{2}(x, y) \leq 0$.

$h_{1}=0, \quad h_{2}=\sqrt{S^{2}(x, y)+H_{E}^{2}}$ and $h_{3}=D_{E}-h_{2}$

3. Three layers: the western shadow zone: $x_{W} \leq x \leq x_{S}$ where $x_{S}$ is defined by $S^{2}\left(x_{S}, y\right)=\left[S^{2}\left(x_{W}, y_{2}\right)+H_{E}^{2}\right]\left[1+\frac{\gamma_{1}}{\gamma_{2}}\left(1-f / f_{2}\right)^{2}\right]-H_{E}^{2}$ and the layer thicknesses are

$$
\begin{aligned}
& h_{1}=-\frac{f / f_{2}}{1+\gamma_{1} / \gamma_{2}} \sqrt{S^{2}\left(x_{W}, y_{2}\right)+H_{E}^{2}}+ \\
& \frac{1}{1+\gamma_{1} / \gamma_{2}} \sqrt{\left(S^{2}+H_{E}^{2}\right)\left(1+\gamma_{1} / \gamma_{2}\right)-\frac{\gamma_{1} f^{2}}{\gamma_{2} f_{2}^{2}} S^{2}\left(x_{W}, y_{2}\right)+H_{E}^{2}} \\
& h_{2}=\frac{f}{f_{2}} \sqrt{S^{2}\left(x_{W}, y_{2}\right)+H_{E}^{2}} \\
& h_{3}=D_{E}-h_{2}-h_{1}
\end{aligned}
$$

OSD

2, 473-505, 2005

The wind-driven overturning circulation of the World Ocean

K. Döös

Title Page

Abstract

Introduction

Conclusions

References

Tables

Figures

14

$\triangleleft$

Back

Close
Full Screen / Esc

Print Version

Interactive Discussion 
4. Three layers: the ventilated zone: $x_{S} \leq x \leq x_{V}$ where $x_{V}$ is defined by $S^{2}\left(x_{v}, y\right)=H_{E}^{2} \frac{\gamma_{1}}{\gamma_{2}}\left(1-f / f_{2}\right)^{2}$ and the layer thicknesses are

$$
\begin{aligned}
& H=\sqrt{\frac{S^{2}+H_{E}^{2}}{1+\frac{\gamma_{1}}{\gamma_{2}}\left(1-f / f_{2}\right)^{2}}} \\
& h_{1}=\left(1-f / f_{2}\right) H, \quad h_{2}=\frac{f}{f_{2}} H, \quad h_{3}=D_{E}-H
\end{aligned}
$$

5. Three layers: the eastern shadow zone: $x_{v} \leq x \leq x_{E}$

$$
h_{1}=\sqrt{\frac{\gamma_{1}}{\gamma_{2}}} S(x, y), \quad h_{2}=H_{E}-h_{1}, \quad h_{3}=D_{E}-H_{E}
$$

Acknowledgements. This work has been financially supported by the Swedish Research Council. I thank P. Killworth for helpful discussions and A. Coward and the rest of the OCCAM team for the model simulation.

\section{References}

10 Broecker, W. S.: The great ocean conveyor, Oceanography, 4, 79-89, 1991.

Bryan, F.: High latitude salinity effects and interhemispheric thermohaline circulations, Nature, 323, 301-304, 1986.

Döös, K. and Webb, D. J.: The Deacon Cell and the other meridional cells in the Southern Ocean, J. Phys. Oceanogr., 24, 429-442, 1994.

Döös, K.: Semi-analytical simulation of the Meridional Cells in the Southern Ocean, J. Phys. Oceanogr., 24, 1281-1293, 1994.

Döös, K. and Coward, A.: The Southern Ocean as the major upwelling zone of North Atlantic Deep Water, WOCE Newsletter, 27, 3-17, 1997.

Drijfhout, S.: Tracing the conveyor belt in the Hamburg large-scale geostrophic ocean general

2, 473-505, 2005

The wind-driven

overturning circulation of the

World Ocean

K. Döös

Title Page

Abstract

Introduction

Conclusions

References

Tables

Figures

14

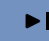

$\triangleleft$

Back

Close

Full Screen / Esc

Print Version

Interactive Discussion 
Ganachaud, A. and Wunsch, C.: Improved estimates of global ocean circulation, heat transport and mixing from hydrographic data, Nature, 408, 453-457, 2000.

Gordon, A.: Interocean exchange of thermocline water, J. Geophys. Res., 91, 5037-5046, 1986.

5 Kalnay, E., Kanamitsu, M., Kistler, R., Collins, W., Deaven, D., Gandin, L., Iredell, M., Saha, S., White, G., Woollen, J., Zhu, Y., Chelliah, M., Ebisuzaki, W., Higgins, W., Janowiak, J., Mo, K. C., Ropelewskia, C., Leetmaa, A., Reynolds, R., and Jenne, R.: The NCEP/NCAR reanalysis project, Bull. Amer. Meteor. Soc., 77, 437-495, 1996.

Killworth, P. D.: Cross-equatorial geostrophic adjustment, J. Phys. Oceanogr., 21, 1581-1601, 1991. Luyten, J. R., Pedlosky, J., and Stommel, H.: The ventilated thermocline, J. Phys. Oceanogr., 13, 292-309, 1983.

Marsh, R., de Cuevas, B. A., Coward, A. C., Bryden, H. L., and Alvarez, M.: Thermohaline circulation at three key sections in the North Atlantic over 1985-2002, Geophys. Res. Lett., 32, L10604, doi:10.1029/2004GL022281, 2005.

15 Munk, W. H.: On the wind-driven ocean circulation, J. Meteor., 7, 79-93, 1950.

Rintoul, S. R.: South Atlantic interbasin exchange, J. Geophys. Res., 96, 2675-2692, 1991.

Nof, D.: The Southern Ocean's grip on the northward meridional flow, Progress in Oceanography, 56, 223-247, 2003.

Semtner, A. J. and Chervin, R.: A thermohaline conveyor belt in the World Ocean, WOCE Notes, 3, 12-15, 1991.

Semtner, A. J. and Chervin, R. M.: Ocean general circulation from a global eddy-resolving model, J. Geophys. Res., 97, 5493-5550, 1992.

Speich, S., Blanke, B., de Vries, P., Döös, K., Drijfhout, S., Ganachaud, A., and Marsh, R.: Tasman leakage: a new route in the global ocean conveyor belt, Geophys. Res. Lett., 29, 10, doi:10.1029/2001GL014586, 2002.

Stevens, D. P. and Thompson, S. R.: The South Atlantic in the Fine Resolution Antarctic Model, Ann. Geophys., 12, 9, 826-839, 1994, SRef-ID: 1432-0576/ag/1994-12-826.

Stommel, H.: The westward intensificationm of wind-driven ocean currents, Trans. Amer. Geophys. Un., 202-206, 1948.

so Trenberth, K. E., Olsen, J. G., and Large, W. G.: A Global Ocean Wind Stress Climatology Based on ECMWF Analyses, NCAR Tech. Note NCAR/TN-338+str, 93 pp., 1989.

Webb, D. J.: An ocean model code for array processor computers, Computers \& Geosciences, 22, 569-578, 1996.

The wind-driven overturning circulation of the World Ocean

K. Döös

Title Page

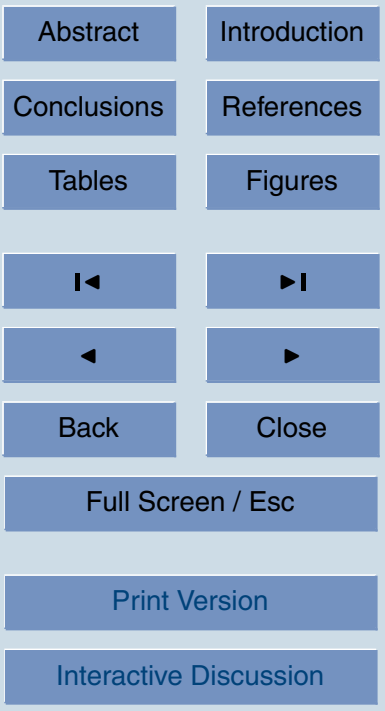

EGU 


\section{OSD}

2, 473-505, 2005

\section{The wind-driven overturning circulation of the World Ocean}

K. Döös

Table 1. Table over the chosen outcropping latitudes with the corresponding Ekman transport for the three oceans.

\begin{tabular}{lcccccc}
\hline & \multicolumn{2}{c}{ Atlantic } & \multicolumn{2}{c}{ Indian } & \multicolumn{2}{c}{ Pacific } \\
& $E(\mathrm{~Sv})$ & latitude & $E(\mathrm{~Sv})$ & latitude & $E(\mathrm{~Sv})$ & latitude \\
\hline$E\left(y_{3 S}\right)$ & $15.9 \mathrm{~Sv}$ & $65^{\circ} \mathrm{S}-50^{\circ} \mathrm{S}$ & $15.9 \mathrm{~Sv}$ & $65^{\circ} \mathrm{S}-50^{\circ} \mathrm{S}$ & $15.9 \mathrm{~Sv}$ & $65^{\circ} \mathrm{S}-50^{\circ} \mathrm{S}$ \\
$E\left(y_{2 S}\right)$ & $8.8 \mathrm{~Sv}$ & $37^{\circ} \mathrm{S}$ & $8.8 \mathrm{~Sv}$ & $37^{\circ} \mathrm{S}$ & $5.5 \mathrm{~Sv}$ & $44^{\circ} \mathrm{S}$ \\
$E\left(y_{2 \mathrm{~N}}\right)$ & $8.0 \mathrm{~Sv}$ & $13^{\circ} \mathrm{N}$ & - & - & $-3.8 \mathrm{~Sv}$ & $40^{\circ} \mathrm{N}$ \\
\hline
\end{tabular}

Title Page

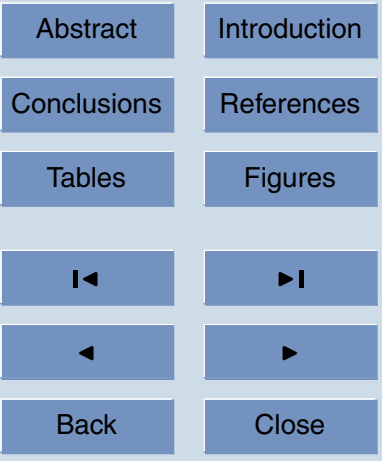

Full Screen / Esc

Print Version

Interactive Discussion 


\section{OSD}

2, 473-505, 2005

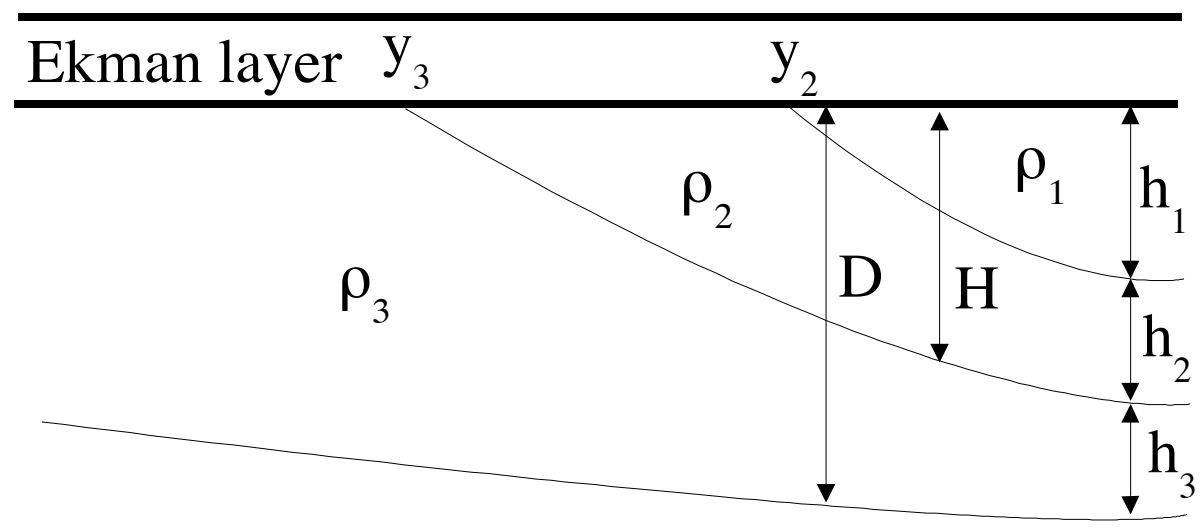

\section{The wind-driven overturning circulation of the World Ocean}

K. Döös

$$
\rho_{4} \quad v_{4}=0
$$

Fig. 1. Schematic meridional cross section of the model. $h_{1}, h_{2}$ and $h_{3}$ are the layer thicknesses. $y_{2}$ and $y_{3}$ are the outcropping latitudes and $\rho$ the density for the different layers. 

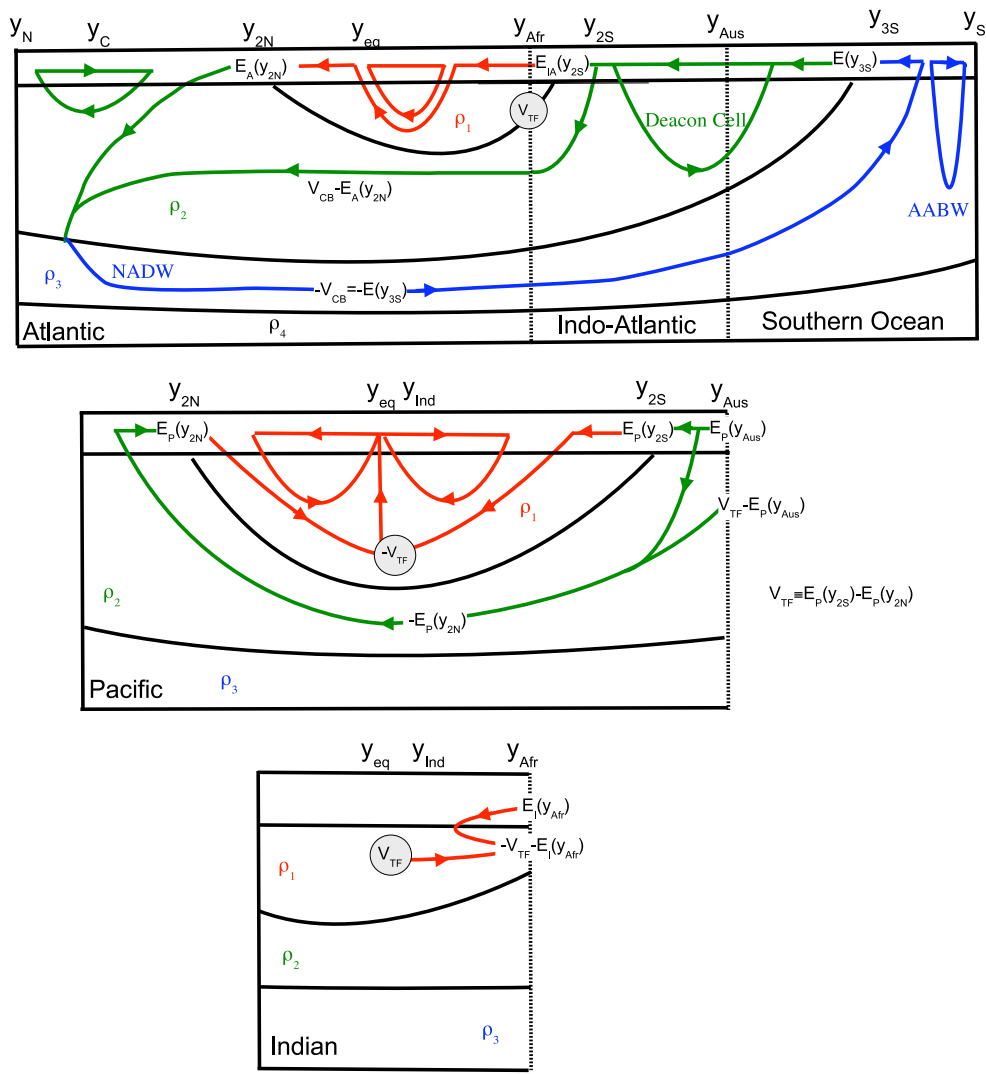

Fig. 2. Schematic meridional cross sections of the model for the different ocean basins. The black lines correspond to the isopycnic interfaces between the density layers and the coloured lines to density layer transports. The circles are inter-ocean exchange transports, with positive numbers for import. $y_{N}$ and $y_{S}$ are the latitudes of the northern and southern boundaries of the model domain. $y_{C}$ is the southernmost latitude of the convection area and $y_{\text {Afr }}$ and $y_{\text {Aus }}$ the southernmost latitudes of Africa and Australia. $y_{\text {Ind }}$ is the latitude of the Indonesian Sea.
OSD

2, 473-505, 2005

The wind-driven

overturning circulation of the World Ocean

K. Döös

\section{Title Page}

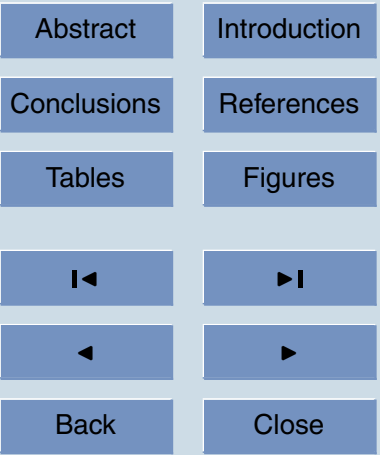

Full Screen / Esc

Print Version

Interactive Discussion 


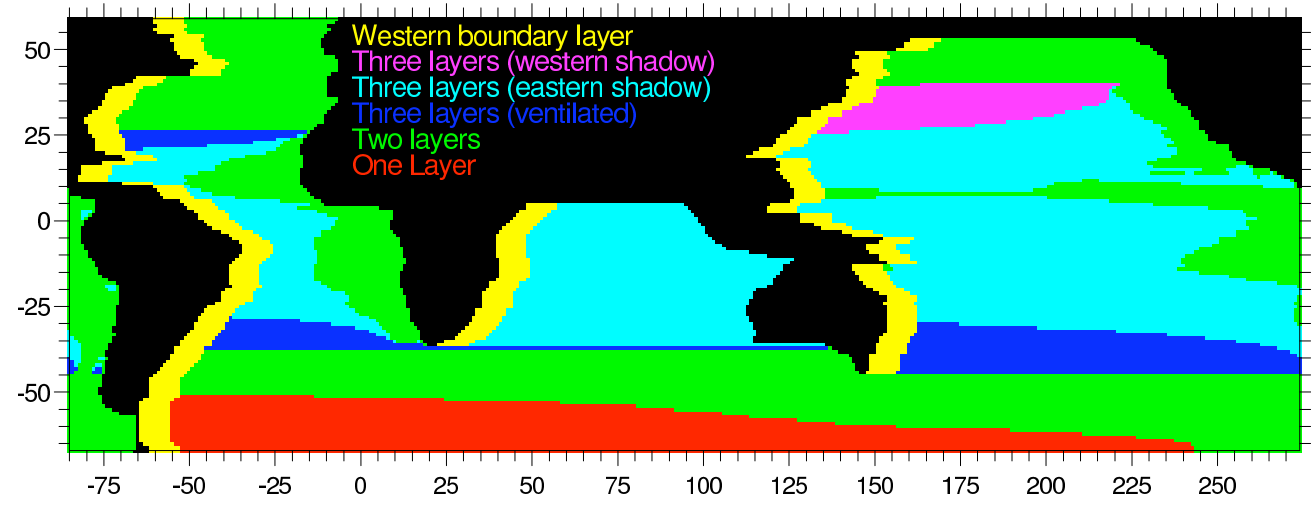

Fig. 3. The LPS regions presented in the Appendix. There is also a western boundary region where the Stommel dynamics have been applied.

\section{The wind-driven overturning circulation of the World Ocean}

K. Döös

Title Page

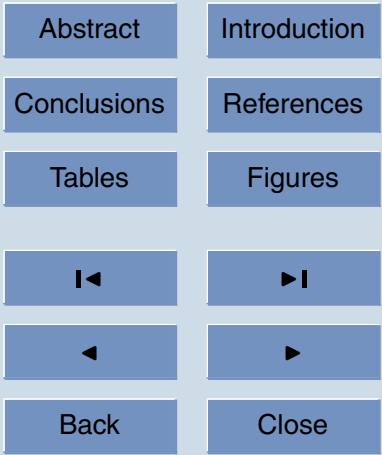

Full Screen / Esc

Print Version

Interactive Discussion 


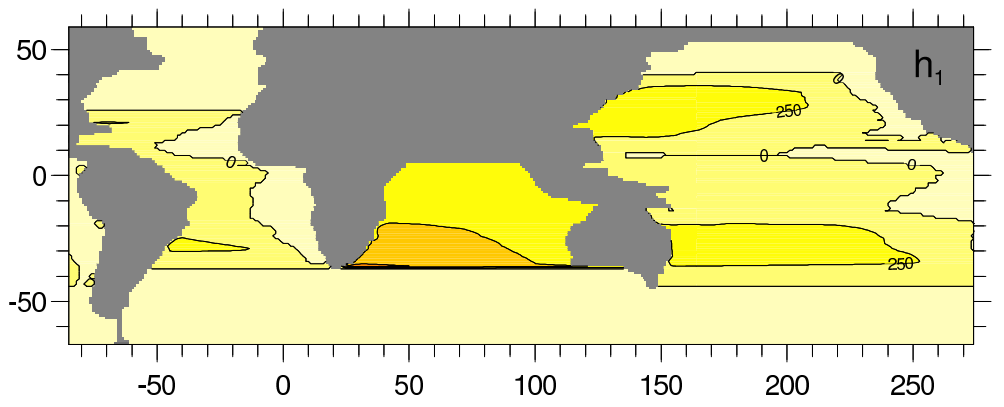

OSD

2, 473-505, 2005

The wind-driven

overturning circulation of the

World Ocean

K. Döös

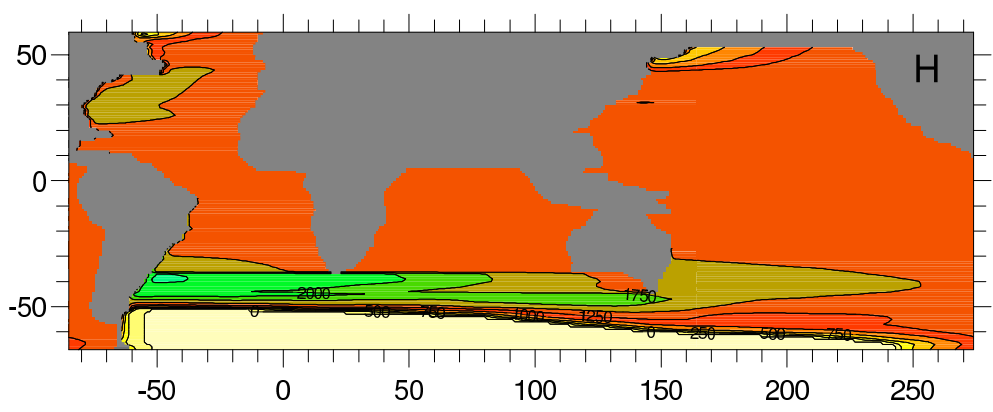

Title Page

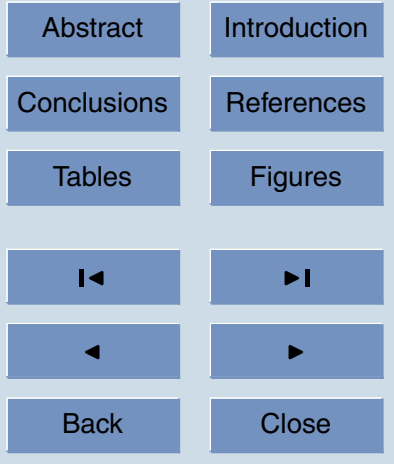

Full Screen / Esc

Print Version

Interactive Discussion

EGU

Fig. 4. The depth of the density layer interfaces simulated by the analytical model. Isolines every $250 \mathrm{~m}$. 
OSD

2, 473-505, 2005

\section{The wind-driven overturning circulation of the World Ocean}

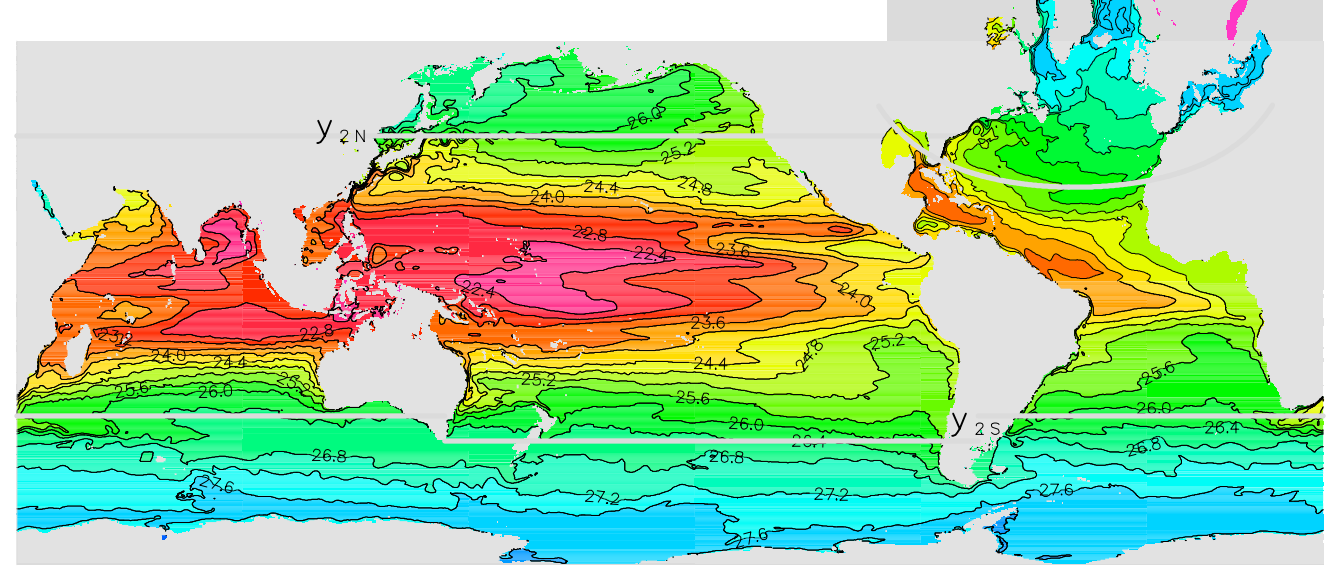

Fig. 5. The $\rho_{0}$-density at $100 \mathrm{~m}$ depth simulated by OCCAM. Units in $\mathrm{kg} / \mathrm{m}^{3}$. The grey lines are the outcropping latitudes $y_{2 N}$ and $y_{2 S}$ of the analytical model.
K. Döös

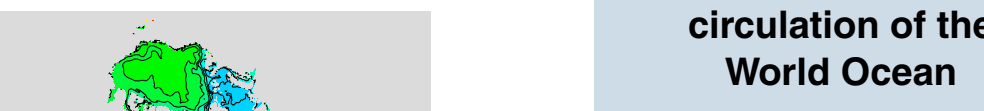

Title Page

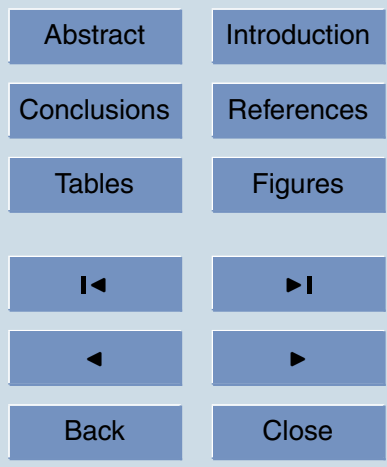

Full Screen / Esc

Print Version

Interactive Discussion 


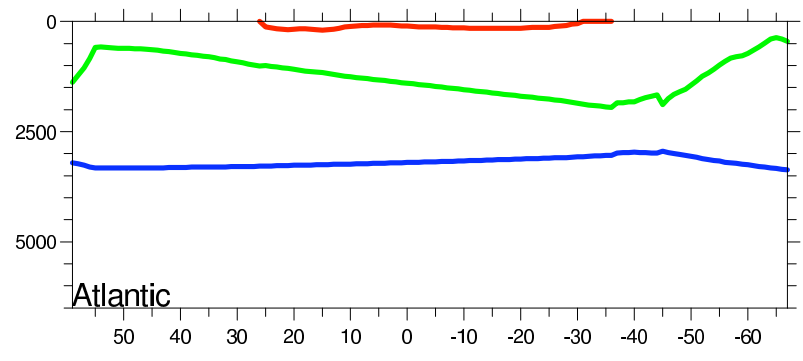

OSD

2, 473-505, 2005

\section{The wind-driven overturning circulation of the World Ocean}

K. Döös
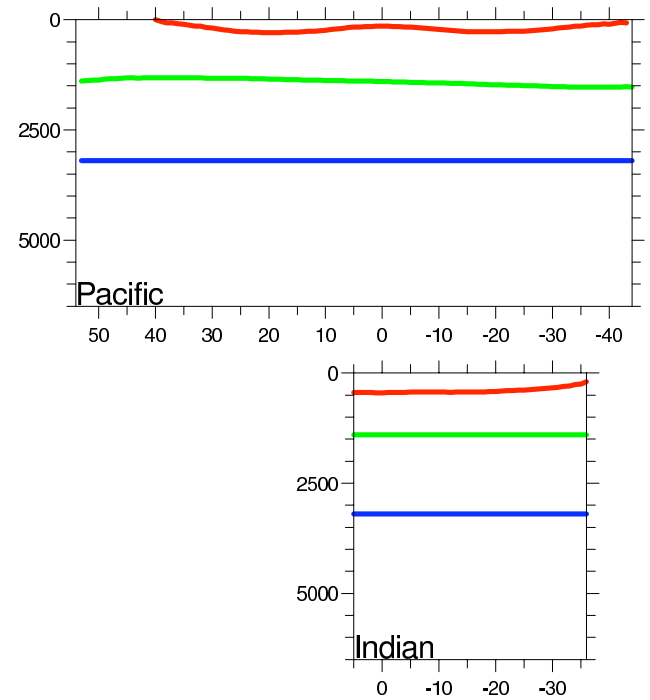

Title Page

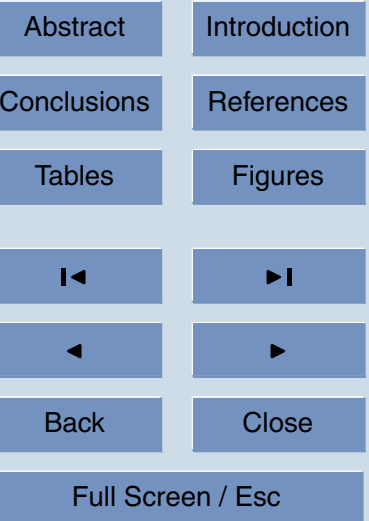

Fig. 6. The depths of the density layer interfaces at the western boundary for the analytical Print Version model. 

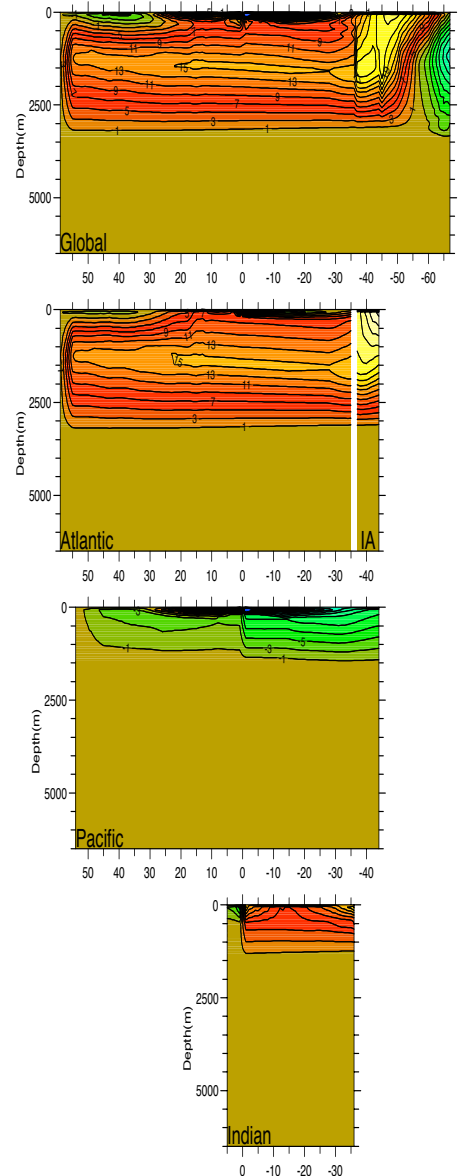
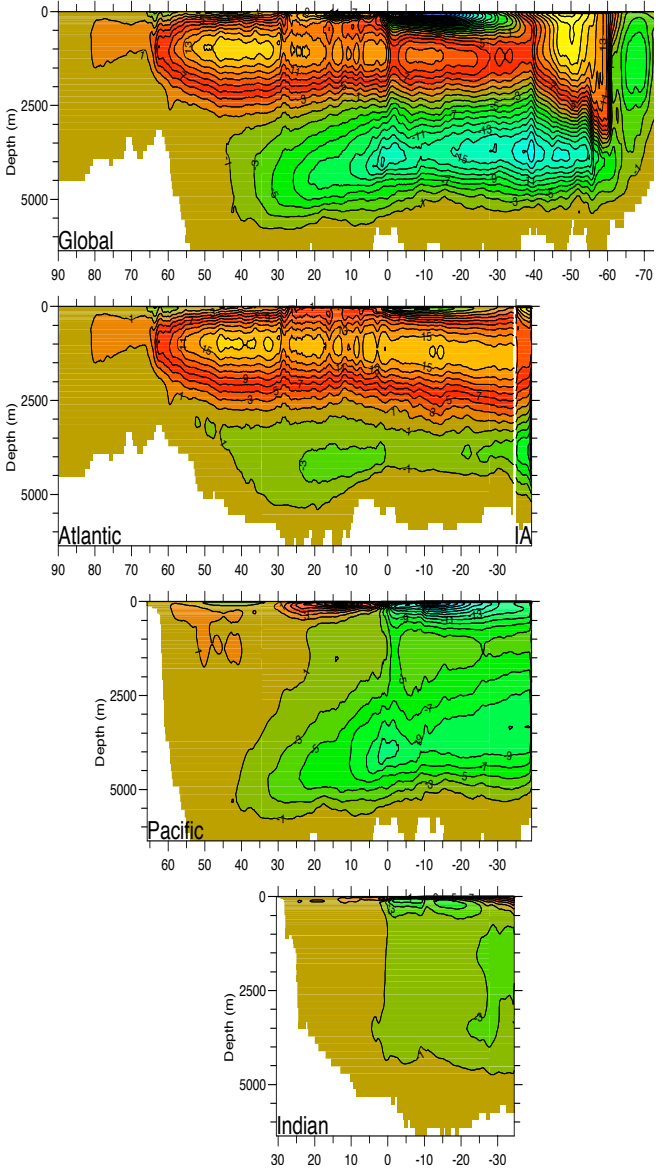

Fig. 7. The meridional overturning stream function in Sv for the three world oceans simulated by the ocean general circulation model OCCAM (right) and the analytical model (left).
OSD

2, 473-505, 2005

The wind-driven

overturning circulation of the

World Ocean

K. Döös

Title Page

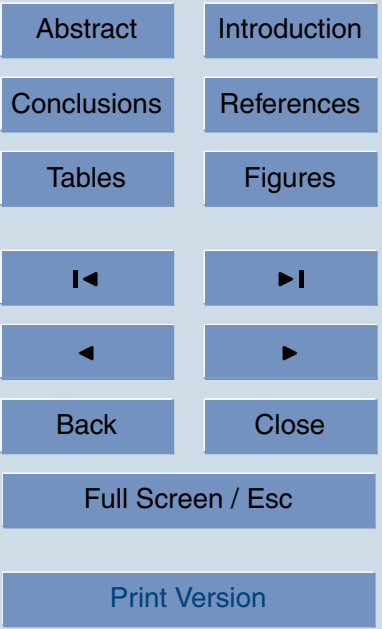

Interactive Discussion 


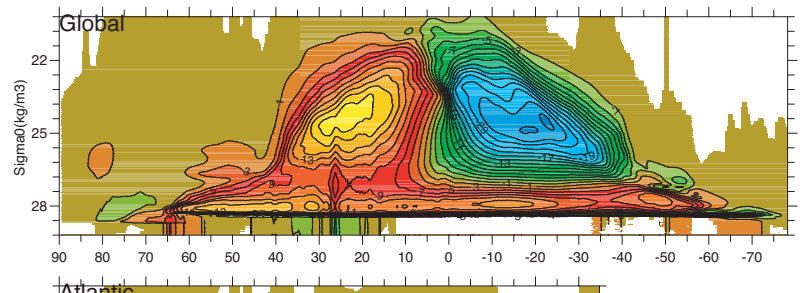

OSD

2, 473-505, 2005
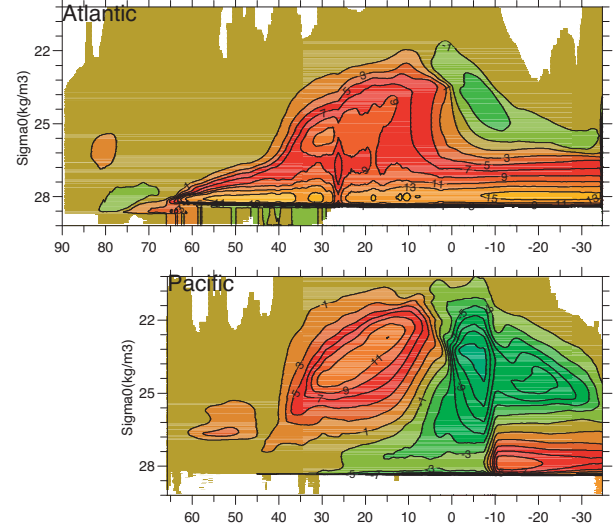

\section{The wind-driven overturning circulation of the World Ocean}

K. Döös

Title Page

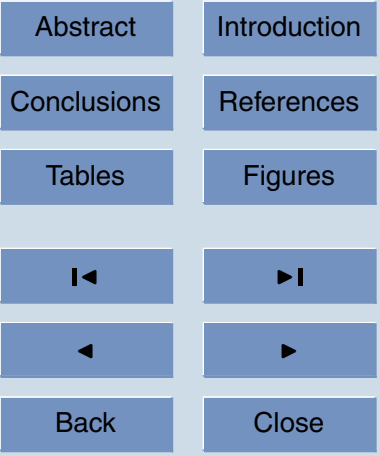

Full Screen / Esc

Print Version

Fig. 8. The meridional overturning stream function as a function of density in Sv for the three world oceans simulated by OCCAM. 
OSD

2, 473-505, 2005

\section{The wind-driven overturning circulation of the World Ocean}

K. Döös

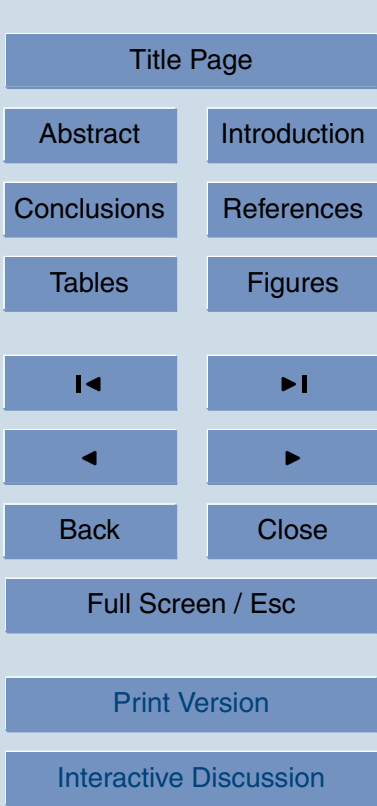

EGU 


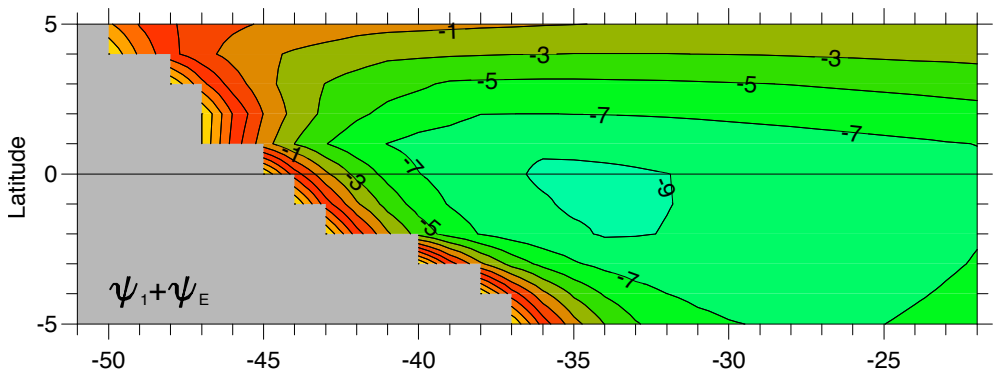

OSD

2, 473-505, 2005

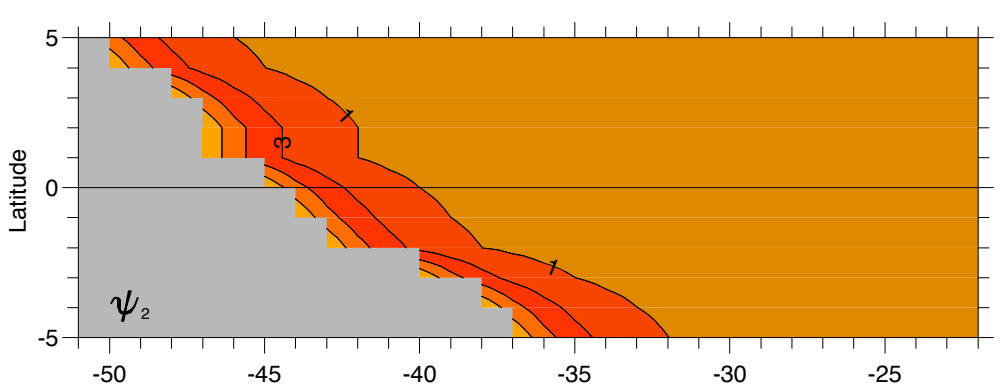

The wind-driven overturning circulation of the World Ocean

K. Döös

\section{Title Page}

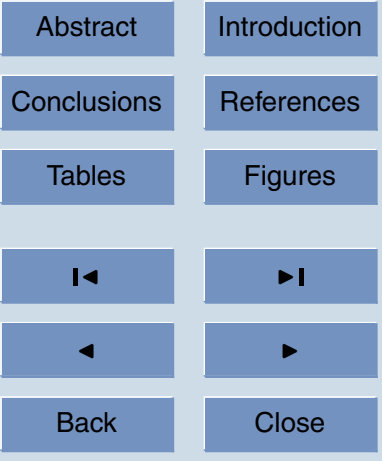

Full Screen / Esc

Print Version

Fig. 10. The horizontal stream function (Sv) for the three layers in the western Equatorial Interactive Discussion 